\title{
ИНСТИТУЦИОНАЛЬНЫЕ ДЕФИЦИТЫ, «ГОСУДАРСТВО БЛАГОДЕНСТВИЯ» И ГОСУДАРСТВЕННАЯ СОЦИАЛЬНАЯ ПОЛИТИКА: СУЩНОСТЬ КОНЦЕПТОВ И МОДЕЛИ ПОЛИТИКИ
}

\section{INSTITUTIONAL DEFICITS, THE «WELFARE STATE» AND STATE SOCIAL POLICY: THE ESSENCE OF CONCEPTS AND POLICY MODELS}

\author{
О.В. Глацких \\ O.V. Glatskikh \\ Среднерусский Институт управления - филиал РАНХиГС, \\ 302028, г. Орел, бульвар Победы, д. 5а \\ Central Russian Institute of management - branch of Ranepa \\ 5a Victory Boulevard, 302028, Orel, Russia \\ E-mail: olgaglats@gmail.com
}

\begin{abstract}
Аннотация
Автор исследует серьезную научно-прикладную проблему институциональных дефицитов, являющихся, с одной стороны, базой социальных проблем. С другой стороны, дефициты коррелируют с отсутствием необходимых у государства ресурсов для проведения эффективной социальной политики. Научная проблематика дефицитов, в том числе институциональных дефицитов, была задействована из экономической теории и интегрирована в исследования государственной социальной политики как самостоятельного направления в политической науке в 70-80 годы XX века. Исследования проблематики дефицитов вне зависимости от социалистической или капиталистической системы качества планирования и управления отраслями и сферами в государстве могут обострять или смягчать явления дефицита. На основе имеющейся теории и эмпирической информации автор анализирует причины появления институциональных дефицитов в современных обществах, включая современную Россию, приводит примеры дефицитов: социальное неравенство, экстерналии, таргетирование государством и бизнесом таких традиционных институтов, как профсоюзы. В данной статье автором предлагается периодизация государственной социальной политики, которую коррелируют с типами государственной социальной политики.
\end{abstract}

\begin{abstract}
The author explores a serious scientific and applied problem of institutional deficits, which are, on the one hand, the basis of social problems. On the other hand, deficits correlate with the lack of resources necessary for the state to implement effective social policy. Scientific problems of deficits, including institutional deficits, were used from economic theory and integrated into the research of state social policy as an independent direction in political science in the 70-80 years of the twentieth century. Research on the problem of deficits, regardless of the socialist or capitalist system, the quality of planning and management of industries and spheres in the state can exacerbate or mitigate the phenomenon of deficits. Based on the available theory and empirical information, the author analyzes the causes of institutional deficits in modern societies, including modern Russia, and provides examples of deficits: social inequality, externalities, and targeting by the state and business of traditional institutions such as trade unions. In this article, the author proposes the periodization of state social policy, which correlate with the types of state social policy.
\end{abstract}

Ключевые слова: социальная политика, институциональные дефициты, государственная социальная политика, государство благоденствия.

Key words: social policy, the institutional deficits of the state social policy, welfare state. 
В последние годы в Российской Федерации, несмотря на значительные усилия института государства, федеральных, региональных и местных властей, острота социальных проблем существенно не снижается. Такое положение дел актуализирует постановку в политическую повестку дня эффективность государственной социальной политики применительно к основным социальным слоям и группам населения. Причем социальная политика государства должна быть проанализирована с последующим принятием политических решений в четырех аспектах.

Во-первых, это соответствие социальных реалий с декларированием в Конституции РФ социального государства. Во-вторых, эффективность функционирования институтов, следствием которого должны стать позитивные институциональные изменения. В-третьих, это наличие институциональных дефицитов, формирующих социальные волнения в обществе. В-четвертых, это реализация государственных программ и национальных проектов, которые ориентированы на преодоление институциональных дефицитов и решение социальных проблем современного российского общества. В этой связи для автора ключевым направлением исследования сложившейся острой социальной ситуации являются концепты «институциональных дефицитов» и «государственной социальной политики».

Научная проблематика дефицитов, в том числе институциональных дефицитов, была задействована из экономической теории и интегрирована в исследования государственной социальной политики как самостоятельного направления в политической науке в 70-80 годы XX века. Одним из разработчиков дефиниции «дефициты» стал Я. Корнаи, который полагал, что синдром дефицита - это «комплексное явление: на его появление влияют несколько факторов. Это проблема как микро-, так и макроуровня» [Корнаи, 1990б, с. 113]. В научном дискурсе о причинах появления и проявлениях дефицита Я. Корнаи акцентировал внимание на том, что дефицит означает, что для реализации какого-либо намерения, плана, к примеру, со стороны института государства, отсутствуют необходимые ресурсы. И при этом «дефицит нельзя описать с помощью одногоединственного показателя» [Корнаи, 1990а, с. 58].

Я. Корнаи видел в социальной сфере, с одной стороны, проявления разных дефицитов, к примеру, рабочей силы на рынке труда, с другой стороны, оборотной стороной дефицитов, как негативного проявления, является проблематика «избытка». Данное понятие исследователь операционализировал в обобщенном смысле, поскольку «избыток», по мнению автора, предполагал негативную, осуждающую коннотацию, свидетельствующую о расточительстве любой политики, о серьезных потерях при использовании ресурсов. При этом, по оценке Я. Корнаи, такой дисбаланс возникал и воспроизводился в рамках любой социально-экономической системы, независимо от того, что, например, характеризует «рынок труда, - дефицит или избыток» [Корнаи, 2012, с. 173].

Кстати, подмечал автор исследования проблематики дефицитов, вне зависимости от социалистической или капиталистической системы качество планирования и управления отраслями и сферами в государстве могут «обострять или смягчать явления дефицита» [Корнаи, 2012, с. 173]. Один из трендов состояния государственной политики занятости в ряде стран Западной и Восточной Европы, бывших республик СССР, может характеризоваться двумя чертами. С одной стороны, наличием резервного рынка труда (безработные), с другой стороны, поисками работодателями трудовых ресурсов. Другими словами, профессиональная квалификация тех, кто ищет работу, не коррелирует с их профессиональной подготовкой, востребованной для новых рабочих мест. И зачастую, по мысли Я. Корнаи, преодолеть этот разрыв невозможно. Еще один ракурс: в условиях избытка может быть характерно и высокое социальное неравенство доходов и уровня благосостояния, что говорит о наличии институциональных дефицитов и системных провалов государственной социальной политики.

Вслед за Я. Корнаи данную проблематику продолжили К. Калхун, М. Олсон, С. Хедлунд. В частности, К. Калхун, директор Лондонской школы экономических и политических наук, выдвинул гипотезу о том, что необходимый для любой страны экономиче- 
ский рост, который обеспечивает система интеракций бизнеса и государства, приносит свои серьезные издержки в виде глобальных проблем в экологии, включая экстерналии, социальных волнений и углубляющегося социального неравенства. При этом К. Калхун поясняет, что параллельно издержкам для различных страт общества главными мишенями такой политики являются «институциональные структуры» [Калхун, 2017, с. 247].

Одним из наиболее сложных институциональных дефицитов в современной России является проблема социального неравенства. Проиллюстрируем это цифрами. К примеру, по информации заместителя директора Института народно-хозяйственного прогнозирования РАН А. Шарова, если в 2008 году «на долю 20 \% наиболее состоятельных домохозяйств приходилось 43,8 \% совокупных денежных доходов» [Пашем..., 2020, с. 6-7], то десятью годами позже (по итогам 2018 г.) - уже 46,2 \%. Как полагает профессор РАНХиГ С.А. Овсянников, уровень социального неравенства в России равен $16 \%$, а по факту «намного больше, коэффициент соотношения богатых и бедных определен на уровне $10 \%$ \% [Неравный враг, 2020, с. 4]. В США этот индикатор равен 16 \%, в ФРГ и скандинавских странах $-7 \%$.

По официальным данным заместителя председателя правительства РФ Т.А. Голиковой, на начало 2000 г. в стране «около 18,5 млн россиян находилось за чертой бедности» [Голикова сообщила..., 2020, с. 2]. Согласно цифрам доктора экономических наук И. Николаева, по итогам 2018 г. (данные исследования банка CreditSuisse) число долларовых миллионеров достигло 246 тыс. человек. При этом, как отмечает данный исследователь, «83 \% общего благосостояния в России находится в руках $10 \%$ состоятельных граждан» [В мире запахло революцией..., 2019, с. 8]. Не лучше ситуация и в мире. Цифры, которые приводятся в исследовании благотворительного объединения Oxfam, в руках «2 153 миллиардеров сосредоточено состояние равное всему, чем владеют 60 \% населения Земли» [Чтобы жить на зарплату..., 2020, с. 12].

Набирающая свой вес в разрезе институциональных дефицитов в российском обществе неблагоприятная экология, экстерналии как следствие алчности бизнеса и попустительства органов власти и управления в регионах РФ. По оценке Счетной палаты, загрязненным воздухом «дышат 56 миллионов жителей России в 143 городах, ежегодно страна теряет около 300 тысяч га леса» [Выжутович, 2020, с. 3]. Более того, агрессивные действия бизнес-структур, расширяющих свои производства без ущерба жизни населения и экологических стандартов, вызывают социальные волнения и акции протеста (протест одного требования). Такие социальные конфликты от произошедших или потенциальных экстерналий возникли в Курской («Мираторг») и Воронежской областях (УГМК).

М. Олсон в своей работе «Власть и процветание» в разрезе институциональных дефицитов подчеркивает факт того, что, к примеру, вред, приносимый загрязнением окружающей среды, является образцовым примером провала рынка. Разумеется, полагает исследователь, фирмы, создающие экологические проблемы, могли бы оплачивать потери общества от загрязнения окружающей среды - часть продукции «обходится обществу дороже, чем получаемый от ее производства выигрыш» [Олсон, 2012, с. 75]. Государство, являясь доминирующим институтом, может обеспечивать снижение транзакционных издержек (действовать более эффективно в интересах граждан). Но они (бизнес и государство) этого во многих случаях не делают, и общество логично становится жертвой данной экстерналии (внешнего эффекта от производства).

О.И. Уильямсон в этом случае предлагает два вида ответных мер со стороны общества: «мотивационные и учетные» [Уильямсон, 1996, с. 340]. В одном случае в рамках публичного управления необходимо мотивировать бизнес для недопущения экстерналий. С другой стороны, в системе взаимодействия государства и общества вести учет экологических издержек, выставляя счет предприятиям (фирмам) за произошедшие экологические катастрофы, негативно повлиявшие на среду и общество.

С. Хедлунд в своем исследовании «Невидимые руки, опыт России и общественная наука» также уделяет большое внимание институциональным дефицитам, приводя в каче- 
стве примера амбициозного перехода страны в 1990-е годы от централизованного планирования и коммунизма к рыночной экономике и капитализму. Этот автор называет процесс перехода системным провалом. Следствием этого провала стали институциональные дефициты (социальное неравенство, таргетирование профсоюзов и других институтов). Кстати, период социального управления в «нулевых» годах XXI века он также оценивает критически «как стабильно провальные попытки государства «вырваться из тисков неудачных институциональных решений» [Хедлунд, 2015, с. 23].

Один из авторитетных отечественных исследователей государственной социальной политики РФ Е.Ш. Гонтмахер отмечает, что в начале 90-х годов исполнительная власть в стране утратила интерес к социальной проблематике, сконцентрировав свои усилия только на экономических преобразованиях, скорее декларативно выстраивая каркас «социальным государства» в Конституции РФ 1993 года. Правда, при этом формировалось законодательство по основным секторам социальной сферы, а также по поддержке наиболее обездоленных категорий населения: пенсионеры, инвалиды, вынужденные переселенцы и др. Кроме того, в правовом режиме был закреплен принцип равенства всех организационно-правовых «форм проведения социальной политики и признано право на существование в социальной сфере негосударственных организаций» [Гонтмахер, 2001, с. 8].

Е. Гонтмахер называет итоги социальных реформ 1990-х годов противоречивыми. Да, институционализировались государственные и негосударственные формы проведения социальной политики, сама политика оформилась в рамках общепризнанных черт. Вместе с тем государственная политика была гигантским шагом назад в сравнении с советским опытом и практиками. Это была политика в интересах крупного бизнеса и олигархата, политика запаздывания и «латания дыр». Основной причиной такого положения дел стало то, что госполитика находилась в противоречии со слабой ресурсной базой для поддержки основных социальных страт, демонстрировавшей провалы государства и рынка в конкретной стране, вызывавшей высокую смертность и массовое общественное озлобление.

Еще один западный исследователь В. Долфсма предложил в своем исследовании выверенную структурную основу для анализа провалов государства в рамках социального и институционального подходов. Более того, данный автор ввел в научный оборот и обосновал четыре основных типа провалов государства. В основе типологизации В. Долфсма лежат правила для акторов, участвующих в управленческих процессах. И эти правила «могут оказаться (1) слишком подробными, (2) слишком общими, (3) волюнтаристскими и (4) конфликтующими с другими правилами» [Долфсма, с. 82]. И, разумеется, такой перечень областей провалов государства, по оценке В. Долфсма, дает нам основание к исследованию различных проблем, к числу которых относятся и институциональные дефициты. Проблемы, ставшие таковыми, в том числе из-за неоптимального или «плохого» управления.

Институциональные дефициты логично отнести к социальным проблемам с характерными подходами к их решению. Кстати, в политической науке сложилась и научная дефиниция типологии проблем - issue typologies. Исследование же социальных проблем в зарубежной и отечественной политической науке осуществляется, как правило, в рамках изучения проблематики политического цикла. При этом, как отмечает Б.Дж. Нельсон, в исследованиях авторами делается основной акцент не столько на моделях действий политических структур на избранных для анализа стадиях политического цикла, а на разнообразных группах проблемных вопросов, каждый из которых по-своему отражает «способ организации отношений между отдельными людьми, социальными группами и государством» [Нельсон, 1999, с. 550].

Характерно, что еще в 50-х годах XX века четыре американских политолога (А. Кэмпбелл, Ф. Конверс, У. Миллер и Д. Стукс) в классической работе «Американский избиратель» выделили два типа проблем: позиционные и знаковые. Исследуя позиционные проблемы, стоит определить их в ракурсе противоречий и разногласий, возникших у конкретных индивидов (акторов) в понимании целей деятельности органов власти и управления, включая правительство национального государства. В свою очередь, знаковые про- 
блемы представляют собой некую подсистему символических предпочтений (комплекс убеждений).

На наш взгляд, логично рассматривать институциональные дефициты, в том числе и в России, с одной стороны, как проблемы, с другой стороны, в данном разрезе обоснованно выделять позиционные и знаковые институциональные дефициты. К примеру, социальное неравенство и экстерналии в РФ стоит рассматривать как позиционные институциональные дефициты, поскольку они являются следствием разногласий различных групп и политических акторов на их возникновение и перспективы их решения. Что касается второго типа проблем, то, к примеру, «дефицит демократии», активно присутствующий в европейском официальном дискурсе, - это знаковый институциональный дефицит. Ведь «дефицит демократии» связан «с механизмами политического представительства» [Шульга, 2014, с. 162-164] как подсистемой символических предпочтений. В этом ракурсе в современной России стоит выделить не только дефицит демократии, но и дефицит гражданского общества, дефицит идентичности, дефицит объединяющей национальной идеи (государственной идеологии).

Кстати, в основе второго типа знаковых проблем находится социальное признание их общезначимости. И, как отмечал основатель символического интеракционизма Дж.Г. Мид, «лучший ключ к этой значимости мы находим в мире, в котором возникают наши проблемы» [Мид, с. 70]. Именно со знаковыми проблемами, которые исследуют и отечественные ученые-политологи, связана символическая политика. По оценке О.Ю. Малиновой, символическую политику стоит представлять как широкую деятельность, ориентированную на производство различных видов «интерпретации социальной реальности» [Малинова, с. 191] и противодействием (борьбой) различных акторов в публичном пространстве. При этом символическая политика не является антагонизмом реальной политики, она является её аспектом.

Политолог из США Теодор Дж. Лоуи, областью исследований которого была американская политика правительства и публичная политика, акцентировал внимание на том, что либеральное государство выросло до огромных размеров присутствия, его модель роста вызвала проблематичные последствия. Данный исследователь полагает, что с возникновением либерализма как общественной философии было положено «начало коррупции современного демократического правительства» [Лоуи, 2003, с. 396]. Правительство, считает автор, отвечая на требования основных организованных групп интересов в стране, разрабатывает и реализует новые стратегии, которые оформляют тиски этих групп интересов на теле государственного организма.

Для определения сущности институциональных дефицитов и их выправления в политических практиках востребованы институты, включая институт государства. В научном политологическом дискурсе относительно института государства, участвующего в решении социальных проблем общества, имеется два основных концепта: «социальное государство» и «государство благоденствия» (welfare-state). По нашему мнению, эти понятия близки, но не тождественны. Западный исследователь Дж. Вейт-Уилсон отмечает, что общепринятого определения государства благосостояния нет. Правда, между государствами, обеспечивающими качественный уровень благосостояния всем социальным стратам, и государствами, которые создают условия благоденствия только для части своих граждан, есть сущностные различия. В данном случае, если государства второго образца хотели бы иметь право именоваться государствами благосостояния, тогда характеристика «государство благоденствия» можно применять к любому государству по той причине, что все индустриальные государства предоставляют социальные блага гражданам, «даже если это только элиты» [Вейт-Уилсон, 2001, с. 130-131].

Значит, вопрос не только и не столько в государстве, в его определении (к примеру, «социальное»), сколько в проводимой им государственной социальной политике. Ряд зарубежных и отечественных исследователей проблематики государственной политики четче конкретизируют содержание «социальной политики». К примеру, Дж. Маджоне справедли- 
во полагает, что социальная политика представляет собой некое равновесие, которое достигается в рамках политического процесса в определенном пространственно-временном континууме «в ходе борьбы соперничающих групп интересов» [Маджоне, 1999, с. 591]. Соответственно, в результате изменения соотношения интересов этих групп и власти изменяется политический курс, реализуемый этой властью. Причем иногда существенно.

Впрочем, преувеличивать соперничество групп интересов, влияющих на изменение курса, не стоит. И на это, к примеру, обращает внимание М. Олсон, справедливо полагающий, что совпадение интересов этих групп не является достаточным условием для создания активных групп, способных заставить правительство прислушаться к их требованиям. Ведь у некоторых групп может оказаться «больше политической силы, чем у других» [Олсон, 2012, с. 80]. И они могут достигнуть сделок с правительством только для себя, а не для приращения общего (коллективного) блага.

Отечественный исследователь В.Д. Роик понимает под социальной политикой то, что она, эта политика, определяет взаимоотношения основных субъектов общества «по поводу социального и материального положения населения» [Роик, 2019, с. 17]. При этом он выделяет социальную политику в рамках всего социума (общества), в организации (корпорации), в регионе, в рамках муниципальных образований (МСУ). А.И. Олейник с понятием «социальная политика» связывает государственное вмешательство в социальные, экономические и политические процессы. При этом автор считает, что под такой политикой логично понимать именно «систематическое воздействие государства на политику домохозяйств на различных ранках» [Олейник, 1998, с. 139].

Разумеется, любой тип государственной политики (государственной социальной политики) в национальном государстве реализуется в рамках устоявшихся моделей такой политики. Анализом теории и прикладных практик при реализации моделей государственной социальной политики занимались как зарубежные ученые (Г. Терборн, Г. Эспинг-Андерсоен, Н. Мэннинг, Т. Маршал, Я. Корнаи и др.), так и отечественные специалисты (С.Н. Надель, В.П. Милецкий, В. Роик и др.). Шведский ученый Й. Терборн, долгое время работавший в Кембридже и занимавшийся изучением социальных проблем, включая проблематику социального неравенства и среднего класса, отмечает в своих работах, что государства стали самыми могущественными структурами коллективной власти, способными осуществлять эффективную социальную политику и решать проблемы институциональных дефицитов.

В своей знаковой работе «Мир: руководство для начинающих» Й. Терборн предложил логично обоснованный тезис о том, что политика XX века создала две успешные формы государства, возникшие в 1960-е годы. Это, как полагает он, в первую очередь западноевропейская модель государства всеобщего благоденствия, основанная на щедрой государственной социальной поддержке, и восточноазиатская модель государства, характеризующуюся «автономным внешним развитием» [Терборн, 2015, с. 143]. Именно в первой модели государства институционализировался, по выражению Й. Терборна, этатизм благосостояния (welfare statism), когда за одно десятилетие уровень государственных доходов и расходов вырос больше, чем за всю предыдущую историю стран Западной Европы. В рамках же второй группы модель государства развития (development state) в Японии распространилась практически на весь регион.

Кроме того, Й. Терборн, опираясь на критерии уровня социальных обязательств института государства и крен этих обязательств, на резервный рынок труда и проблематику занятости, выделил четыре типа социальной политики государства. Во-первых, интервенционалистское государство, реализующее расширительную политику в интересах социума (скандинавские государства). Во-вторых, это государство «мягкого» благосостояния, при котором его роль сводится к задействованию компенсаторских механизмов при реализации социальной политики (Бенилюкс). В-третьих, это, как правило, англосаксонские государства, реализующие социальную политику с учетом рыночных механизмов. 
И, в-четвертых, это государства с невысокими социальными обязательствами при осознанной высокой занятости населения (Япония).

Специалист по государственному управлению из Великобритании Н. Мэннинг, исследуя эффективность государственных учреждений, отмечал, что в научной и экспертной среде ширится признание того, что госучреждения имеют высокое значение для развития, но совершенно неясно, какие именно учреждения являются наиболее значимыми, в особенности для реализации социальной политики. Этот ученый выделял следующие модели государственной социальной политики: корпоративную, марксистскую, плюралистическую модели и модель элит. Кроме того, Н. Меннинг полагал, что государственные учреждения нуждаются в реформах. А именно в снижении госрасходов, в повышении их способностей к развитию, к улучшению выполнения институтом государства функций эффективного работодателя, к повышению качества предоставления социальных услуг [Мэннинг, 2003, с. 42-43].

В своих исследованиях экс-президент Международной ассоциации политических наук Т.Дж. Лоуи представил и обосновал типологию проблем (данные материалы были потом переданы правительственным структурам и в конгресс США). Он видел эти проблемы в следующих разрезах. Во-первых, в зависимости от принуждения федерального правительства, которое применяет этот рычаг давления прямо на индивидов или социальные группы или опосредованно, посредством создания соответствующих условий. Вовторых, угрозой применения принуждения в краткосрочной, среднесрочной или долгосрочной перспективе. И, как реакция на возникающие проблемы, Т.Дж. Лоуи типологизировал реализуемую правительством государственную политику, выделив распределительную, перераспределительную, регулируемую и законодательную политики.

По мнению Т.Дж. Лоуи, данная типология будет ориентирована на ученых и практиков в подготовке и принятии политических решений, в том числе и в социальной сфере, вне зависимости от конкретных национальных государств. При этом если рассматривать по Т.Дж. Лоуи каждую политику, то в ней изначально закладываются как позитивные, так и негативные аспекты. К примеру, распределительная политика представляет собой некую «кормушку», ресурсы от правительства, направленные на конкретных получателей. Разумеется, при ее реализации есть и победители (определенные социальные группы), но есть проигравшие, которые и платят за это распределение.

Если вести речь о перераспределительной политике, то она предполагает передачу ресурсов от одной социальной страты (набора индивидов, социальных групп) к другой, выбранной посредством политического решения (правительством, парламентом или чаще всего совместным решением). Законодательная политика, насколько можно судить о ней, учреждает правила по отношению к индивидам, социальным группам на доступ к ресурсам общества (иногда ее еще называют учредительной политикой). Политика регулирования предполагает государственный дирижизм для достижения публичных целей социальной справедливости и ориентирована только на определенные классы или группы. В этом случае институт государства изыскивает дополнительные ресурсы и повышает затраты в реализации своей политики для достижения поставленных целей.

Свою типологию государственной социальной политики предложил и зарубежный политолог Т.А. Смит, который исследовал связь между функционированием политической системы и характером публичной политики. При этом стоит отметить, что сама дефиниция «публичная политика» в российской политической науке разными исследователями понималась и понимается по-разному. Среди вариантов перевода термина в отечественной науке встречались разнообразные понятия: «открытая», «общественная политика», «государственно-публичная политика», иногда даже термин отождествлялся с социальной политикой [Публичная политика, 2008, с. 6]. В данном случае для нас ближе последний вариант, который предполагает корреляцию публичной политики с открытой государственной социальной политикой в интересах общества. 
В данном случае Т.А. Смит понимал всю сложность, конфликтность публичной политики и исследовал двенадцать примеров реализации такой политики в пяти странах западной демократии (Великобритании, США, Канада, ФРГ, Франция) с выделением четырех политических курсов. Данный ученый дал определение такой политике, понимая под государственной (публичной) политикой совокупность правительственных решений, основанных на проблемах. В это понятие он включал и принятие решений политическими элитами, и борьбу групп интересов, и системный анализа Д. Истона о «входе» и «выходе». При этом в рамках политического процесса автор концентрировал основное внимание на шаблонном потоке вопросов, которые в конечном итоге становятся правительственными решениями.

Проводя дифференциацию политических курсов, Т.А. Смит выстраивал их на основании сравнения властных акторов и процессов принятия решений. В результате данный исследователь предложил и обосновал четыре основных типа публичной политики: 1) распределительная политика, 2) секторально фрагментированная политика, 3) эмоциональная политика, 4) перераспределительная политика. Автор полагал, что распределительную политику отличают конфликты небольшой интенсивности, которые отмечены малой вовлеченностью различных участников, так как люди, организации, департаменты правительства в значительной степени «не конкурируют с интересами других акторов в их обращении за помощью к правительству» [Smith, 1975, p. 34]. На наш взгляд, есть основание полагать, что распределительная политика реализуется чаще, чем любой другой тип политики, и в комплексе мероприятий в деятельности многих правительств развитых стран мира представлена в большей мере. И во многом это связано с новым контекстом взаимодействия между различными «отраслевыми и корпоративными интересами, социальными партнерами и социальными группами» [Люблинский, 2008, с. 131].

В свою очередь, секторально фрагментированная политика, по Т.А. Смиту, отличается от распределительной политики главным образом своей способностью вовлекать гораздо большее число индивидов и социальных групп в конфликт, которые становятся разделимы из-за разногласий, связанных с представляемыми ими секторами. Секторально фрагментированная политика проявляется умеренно в уровне конфликтов, «степень которых определяется как размером социально-экономического сектора, так и количеством, и видами интересов» [Smith, 1975, p. 65]. В нее вовлечены группы интересов, НКО, депутаты парламентов, в том числе от политических партий, министры отраслевых министерств, заинтересованные в решении конкретных проблем отраслевых интересов. Возникающие вопросы в рамках данного типа политики решаются только в рамках законодательного органа.

Эмочиональная политика является наиболее демократичной из всех видов, выделенных Т.А. Смитом, если под демократией понимать широкомасштабное политическое участие и вовлеченность индивидов и групп, а также контроль над последствиями принятия политических решений. Демократические процедуры при реализации эмоциональной политики проявляются следующим образом. Высокая интенсивность конфликта по вопросам «образа жизни», где важную роль в политическом процессе играют не политические партии и депутаты (их влияние становится не настолько сильным, а в ряде случаев подорванным), а обычные агенты, поддерживаемые группами интересов со значительной акцентацией на традиции и мораль конкретного общества.

Политику перераспределения характеризует крупномасштабный конфликт, в котором основные участники более или менее следуют традиционным классовым линиям. Подобно эмоциональному, этот тип политики также включает значительное количество участников. Правда, конфликт при этом более структурирован и его границы более предсказуемы, менее разбросаны по разным социально-экономическим слоям. Перераспределительный тип политики характеризуется тем, что борьба происходит между интересами среднего класса и наемными рабочими, между силами правого и левого идеологического 
спектра. При реализации такой политики возможны беспорядки, демонстрации, забастовки и иные политические акции.

Основными акторами такой перераспределительной политики является политическое руководство страны с одной стороны и лидеры профессиональных ассоциаций, представляющие интересы класса наемных рабочих, с другой стороны. Ключевые политические решения в данном случае принимаются, как правило, главами государств и руководителями правительств в ходе переговоров с представителями основных профессиональных ассоциаций. Высоко участие политических партий, при этом законодательная власть демонстрирует относительное спокойствие и стабильность. При этом, как подчеркивает отечественный исследователь Л.В. Сморгунов, тот или иной тип публичной политики (фактически набор или спектр решений правительств по спорным вопросам) используется в различных странах при решении конкретных проблем и «не составляет устойчивой характеристики той или иной демократической системы» [Сморгунов, 2018, с. 392].

Рассматривая институциональные дефициты в РФ, которые имеют отношение к государственной социальной политике, стоит сделать ряд предварительных выводов. Дефициты как базовые социальные проблемы (они очерчены в начале исследования) требуют конкретных мер по их разрешению (в рамках госпрограмм, федеральных целевых программ, национальных проектов и с помощью других механизмов и инструментов). Имеющиеся в Конституции РФ положения о социальном государстве скорее несут в себе символический ориентир, достигаемый в среднесрочной перспективе. Категория же «государства всеобщего благоденствия», которая как практика уже сложилась в ряде государств Запада и имеет приоритет для нашей страны, является ориентиром в долгосрочной перспективе.

Опираясь на имеющуюся теоретико-методологическую основу типологии политик (Т. Дж. Лоуи, Т.А. Смит), эмпирические данные по институциональным дефицитам, ряду характеристик социальных проблем в постсоветской России, стоит предложить и авторскую периодизацию государственной социальной политики с коррелированием этих этапов с типами государственной социальной политики.

Итак, первый этап (1992-2003 гг.) связан с эмоциональной политикой. Эта политика представляла собой широкую вовлеченность индивидов и групп при скудных государственных ресурсах в постсоветской России, измученной «шоковой терапией» в экономике и взбудораженной хаотичной демократизацией. Данный этап характеризуется в первую очередь высокой интенсивностью конфликта индивидов и социальных страт между собой по вопросам «образа жизни» (деление на адептов «советско-социалистической» и «либерально-западной» идеологем). Следствием этой эмоциональной политики, инициированной радикальными экономическими реформами правительства младореформаторов Е. Гайдара, стало массовое обнищание населения, деградация социальной инфраструктуры и учреждений.

Второй этап (2004-2017 гг.) представлял собой секторально-фрагментированную политику, реализуемую в рамках умеренных конфликтов по поводу распределения увеличивающихся ресурсов государства ресурсов за счет оживления экономики между отраслями и секторами социальной сферы. В рамках данной политики свое влияние оказывали парламентские политические партии, НКО, министерства и ведомства, группы интересов. Именно в эти годы были сделаны попытки в преодолении институциональных дефицитов в рамках новых явлений: «материнский капитал», 4 приоритетных нацпроекта («Образование», «Здравоохранение», «Развитие АПК» с ориентиром на повышение уровня жизни в сельских территориях, «Доступное комфортное жилье - гражданам России»), ФЦП (федеральные целевые программы) и госпрограмм.

И третий этап (с 2018 года по настоящее время) связан с перераспределительной политикой, в которой задействован широкий круг участников (акторов), характеризующейся высокой конфликтностью. Правда, со структурированием границ конфликта и его предсказуемым развитием. К примеру, в рамках данного этапа прогнозируется решение 
вопроса о введении прогрессивной шкалы налогообложения (более низкой для бедных, более высокой для обеспеченных слоев населения). Особую роль на данном этапе и в рамках перераспределительной политики играют и будут играть 12 национальных проектов, которые ориентированы на выравнивание возможностей для всех слоев социальных страт российского общества и решение целей национального развития.

\section{Список литературы}

1. В мире запахло революцией. Социальное неравенство выливается в массовые уличные протесты. 2019. Московский комсомолец. РРЕ. 27 ноября - 4 декабря: 8.

2. Вейт-Уилсон Дж. 2001 Государство благосостояния: проблема в самом понятии. Pro et Contra. 6(3): 128-158.

3. Выжутович В. 2020. Среда окружает. Российская газета. 7 февраля: 3.

4. Голикова сообщила, что за чертой бедности живет 18,5 млн россиян. 2020. Коммерсант. 27 января: 2.

5. Гонтмахер Е.Ш. 2001 Социальная политика в России: эволюция 90-х и новый старт. Pro et Contra. 6(3): 7-22.

6. Долфсма, В. 2017 Провалы государства. Общество, рынки и правила. М., Изд-во Института Гайдара, 256 с.

7. Калхун К. 2017. Что грозит капитализму сегодня. М., Изд-во Института Гайдара, 265.

8. Корнаи Я. 1990. Дефицит. М., Наука, 608.

9. Корнаи Я. 1990 Путь к свободной экономике: страстное слово в защиту экономических преобразований. М., Экономика, 149.

10. Корнаи Я. 2012. Размышления о капитализме. М., Издательство Института Гайдара, 352.

11. Лоуи Т. Дж. 2003. Конец либерализма: обвинительный акт. М., Изд-во МГУ, 400.

12. Люблинский В.В. 2008. Социальная политика в условиях глобализации: опыт развитых стран. Полис. 6: 130-146.

13. Маджоне Дж. 1999. Социальная политика и управление: идеи, интересы и институты. М., Вече, 607.

14. Малинова О.Ю. 2015. Символическая политика: осмысление предметного поля. В кн. Сморгунов Л.В. Российская политическая наука: Идеи, концепции, методы. М., Издательство «Аспект Пресс», 195.

15. Мид Дж. Г. 2014. Философия настоящего. М., Изд. дом Высшей школы экономики, 272.

16. Мэннинг Н. 2003. Реформа государственного управления: международный. М., Издательство «Весь Мир». 496.

17. Нельсон Б.Дж. 1999. Социальная политика и управление: общие проблемы / Б.Дж. Нельсон // Политическая наука: новые направления / Пер. с англ. М.М. Гурвица, А.Л. Демчука, Т.В. Якушевой. Под ред. Р. Гудина и Х.-Д. Клингеманна. Научный редактор русского издания Е.Б. Шестопал. М., Вече, С. $527-569$.

18. Неравный враг. Бедность стала темой сессии «Русского дома» в Давосе. 2020. Известия. 23 января, с. 4. $139-144$

19. Олейник А.Н. 1998. Социальная политика: пути достижения эффективности. Полис. 5:

20. Олсон М. 2012. Власть и процветание: Перерастая коммунистические и капиталистические диктатуры. М., Новое издательство, 212.

21. «Пашем с утра до ночи, а в кошельке пусто. Одним едва хватает на еду и оплату ЖКУ, а другие не знают, на что бы еще потратить пару миллионов. 2020. Аргументы и факты. 21 января, c. $6-7$.

22. Публичная политика: от теории к практике. 2008. СПб., Алетейя, 356.

23. Роик В.Д. 2019. Социальная политика и технологии социальной работы. М., Юрайт, 522.

24. Сморгунов Л.В. 2018. Политические режимы, стили и режимы публичной политики. В кн. Соловьев А.И. Государственная политика и управление. М., Издательство «Аспект Пресс», 409. 
25. Терборн Й. 2015. Мир: руководство для начинающих. М., Нац. исслед. ун-т «Высшая школа экономики», 336.

26. Уильямсон О.И. 1996. Экономические институты капитализма: фирмы, рынки, «отношенческая» контрактация. СПб., Лениздат; CEVPress, 702.

27. Хедлунд, С. 2015. Невидимые руки, опыт России и общественная наука. Способы объяснения системного провала. М., Издательский дом Высшей школы экономики, 424.

28. Чтобы жить на зарплату безбедно. Как состояние экономики может снизить бедность в стране. 2020. Российская газета. 22 января, 12.

29. Шульга М.А. 2014. «Дефицит демократии» в Европейском союзе: Смыслы и интерпретации. Политическая наука. Трансформация европейского пространства. 2: 162-183.

30. Smith T.A. 1975. The comparative policy process. Clio Press, Inc, 184.

\section{References}

1. V mire zapahlo revoljuciey. Social'noe neravenstvo vylivaetsja $v$ massovye ulichnye protesty [The world smelled of revolution. Social inequality translates into massive street protests]. Moskovskij komsomolec 2019. RRE. 27 nojabrja - 4 dekabrja: 8 (in Russian).

2. Vejt-Uilson Dzh. 2001 Gosudarstvo blagosostojanija: problema v samom ponjatii [Welfare state: a problem in the concept itself]. Pro et Contra. 6(3): 128-158 (in Russian).

3. Vyzhutovich V. 2020. Sreda okruzhaet [The environment is surrounding]. Rossijskaja gazeta [Russian newspaper] 7 fevralja: 3 (in Russian).

4. Golikova soobshhila, chto za chertoj bednosti zhivet $18,5 \mathrm{mln}$ rossijan [Golikova said that 18.5 million Russians live below the poverty line]. 2020. Kommersant. 27 janvarja: 2 (in Russian).

5. Gontmaher E.Sh. 2001 Social'naja politika v Rossii: jevoljucija 90-h i novyj start [Social policy in Russia: the evolution of the 90s and a new start]. Pro et Contra. 6(3): 7-22 (in Russian).

6. Dolfsma, V. 2017 Provaly gosudarstva. Obshhestvo, rynki i pravila [State failures. Society, markets and rules]. M., Izd-vo Instituta Gajdara [Publishing House of the Gaidar Institute], 256 s. (in Russian).

7. Kalhun K. 2017. Chto grozit kapitalizmu segodnja [What threatens capitalism today]. M., Izd-vo Instituta Gajdara [Publishing House of the Gaidar Institute], 265 (in Russian).

8. Kornai Ja. 1990. Deficit. M., Nauka, [The Science] 608 (in Russian).

9. Kornai Ja. 1990 Put' k svobodnoj jekonomike: strastnoe slovo v zashhitu jekonomicheskih preobrazovanij [The path to a free economy: passionate word in defense of economic transformation]. M., Jekonomika [The economy], 149 (in Russian).

10. Kornai Ja. 2012. Razmyshlenija o kapitalizme [Reflections on Capitalism]. M., Izdatel'stvo Instituta Gajdara [Publishing House of the Gaidar Institute], 352 (in Russian).

11. Loui T. Dzh. 2003. Konec liberalizma: obvinitel'nyj akt [The End of Liberalism: The Indictment] M., Izd-vo MGU [Publishing of Moscow state Univercuty], 400 (in Russian).

12. Ljublinskij V.V. 2008. Social'naja politika v uslovijah globalizacii: opyt razvityh stran [Social policy in the context of globalization: the experience of developed countries]. Polis. 6: 130-146 (in Russian).

13. Madzhone Dzh. 1999. Social'naja politika i upravlenie: idei, interesy i instituty [Social policy and management: ideas, interests and institutions]. M., Veche, 607 (in Russian).

14. Malinova O.Ju. 2015. Simvolicheskaja politika: osmyslenie predmetnogo polja. V kn. Smorgunov L.V. Rossijskaja politicheskaja nauka: Idei, koncepcii, metody [Symbolic politics: understanding the subject field]. M., Izdatel'stvo «Aspekt Press», 195 (in Russian).

15. Mid Dzh. G. 2014. Filosofija nastojashhego [The philosophy of the present]. M., Izd. dom Vysshej shkoly jekonomiki [House of the Higher School of Economics]. 272 (in Russian).

16. Mjenning N. 2003. Reforma gosudarstvennogo upravlenija: mezhdunarodnyj [Public Administration Reform: International]. M., Izdatel'stvo «Ves' Mir» [The Whole World]. 496 (in Russian).

17. Nel'son B. Dzh. 1999. Social'naya politika i upravlenie: obshchie problemy [Social policy and governance: common problems] B.Dzh. Nel'son // Politicheskaya nauka: novye napravleniya / Per. S angl. M.M. Gurvica, A.L. Demchuka, T.V. Yakushevoj. Pod red. R. Gudina i H.-D. Klingemanna. Nauchnyj redaktor russkogo izdaniya E.B. Shestopal. M., Veche, 527 - 569 (in Russian).

18. Neravnyj vrag. Bednost' stala temoj sessii «Russkogo doma» v Davose [The unequal enemy. Poverty became the topic of the session of the Russian House in Davos]. 2020. Izvestija. [The News] 23 janvarja, s. 4. (in Russian). 
19. Olejnik A.N. 1998. Social'naja politika: puti dostizhenija jeffektivnosti [Social policy: ways to achieve efficiency] Polis. 5: 139-144 (in Russian).

20. Olson M. 2012. Vlast' i procvetanie: Pererastaja kommunisticheskie i kapitalisticheskie diktatury [Power and Prosperity: Outgrowing Communist and Capitalist Dictatorships]. M., Novoe izdatel'stvo [New Publishing]. 212 (in Russian).

21. Pashem s utra do nochi, a v koshel'ke pusto. Odnim edva hvataet na edu i oplatu ZhKU, a drugie ne znajut, na chto by eshhe potratit' paru millionov [We plow from morning to night, and in the wallet is empty. One is barely enough for food and utility bills, while others do not know what else to spend a couple of million]. 2020. Argumenty i fakty [Arguments and facts]. 21 janvarja, s. 6-7 (in Russian).

22. Publichnaja politika: ot teorii k praktike [Public policy: from theory to practice]. 2008. SPb., Aletejja, 356 (in Russian).

23. Roik V.D. 2019. Social'naja politika i tehnologii social'noj raboty [Social policy and social work technologies]. M., Jurajt, 522 (in Russian).

24. Smorgunov L.V. 2018. Politicheskie rezhimy, stili i rezhimy publichnoj politiki [Political regimes, styles and public policy regimes]. V kn. Solov'ev A.I. Gosudarstvennaja politika i upravlenie. M., Izdatel'stvo «Aspekt Press» [Aspect Press Publisher]. 409 (in Russian).

25. Terborn J. 2015. Mir: Rukovodstvo dlja nachinajushhih [World: A Beginner's Guide]. M., Nac. issled. un-t «Vysshaja shkola jekonomiki» [Nat. researched University «Higher School of Economics»], 336 (in Russian).

26. Uil'jamson O.I. 1996. Jekonomicheskie instituty kapitalizma: Firmy, rynki, «otnoshencheskaja» kontraktacija [Economic Institutions of Capitalism: Firms, Markets, «Relational» Contracting]. $\mathrm{SPb}$., Lenizdat; CEVPress, 702 (in Russian).

27. Hedlund, S. 2015. Nevidimye ruki, opyt Rossii i obshhestvennaja nauka. Sposoby ob\#jasnenija sistemnogo provala [Invisible hands, the experience of Russia and social science. Ways to explain a system failure]. M., Izdatel'skij dom Vysshej shkoly jekonomiki [Publishing House of the Higher School of Economics]. 424 (in Russian).

28. Chtoby zhit' na zarplatu bezbedno. Kak sostojanie jekonomiki mozhet snizit' bednost' v strane [To live comfortably on a salary. How the state of the economy can reduce poverty in the country]. 2020. Rossijskaja gazeta [Russian Paper]. 22 janvarja, 12 (in Russian).

29. Shul'ga M.A. 2014. «Deficit demokratii» v Evropejskom sojuze: Smysly i interpretacii [The «Deficit of Democracy» in the European Union: Meanings and Interpretations] Politicheskaja nauka. Transformacija evropejskogo prostranstva [Political science. Transformation of the European space]. 2: 162-183 (in Russian).

30. Smith T.A. 1975. The comparative policy process. Clio Press, Inc, 184.

\section{Ссылка для цитирования статьи Link for article citation}

Глацких О.В. Институциональные дефициты, «государство благоденствия» и государственная социальная политика: сущность концептов и модели политики. Via in tempore. История. Политология, 47 (2): 437-448. DOI 10.18413/2687-0967-2020-47-2-437-448.

Glatskikh O.V. Institutional deficits, the «welfare state» and state social policy: the essence of concepts and policy models. Via in tempore. History and political science, 47 (2): 437-448 (in Russian). DOI 10.18413/2687-0967-2020-47-2-437-448. 